\title{
Non-Structural Earthquake Risk Management for Residential Buildings
}

\author{
Sólveig Thorvaldsdottir*,1, Bjarni Bessason ${ }^{1}$, and Rajesh Rupakhety ${ }^{1}$ \\ (1) Earthquake Engineering Research Centre, Faculty of Civil and Envionmental Engineering, University of Iceland, \\ Austurvegur 2A, 800 Selfoss, Iceland
}

Article history: received March 24, 2020; accepted September 1, 2020

\begin{abstract}
As buildings become more resilient against structural damage the cost of non-structural damage and their consequences becomes proportionally higher, giving non-structural damage greater importance in earthquake risk reduction. Providing residents with detailed guidance on how to evaluate their risk regarding non-structural earthquake damage, and what mitigation and preparedness options they have, can increase both home and societal earthquake resiliency. Earthquake damage data from destructive earthquakes in south Iceland in 2000 and 2008 were used to develop simple but detailed twelve-step risk-management guidelines for residents. The guidelines are based on a set of disaster-related objectives. A standard loss estimation study was used to develop guidelines for the fixed non-structural elements whilst photographs from inside homes that had sustained significant non-structural damage were used to develop guidelines for loose items. Virtually every item in the studied homes was considered to understand its importance and its relevance to the function of a home. Information in terms of financial, functional and emotional value were used in the guidelines to help residents decide which mitigation options to take. The photos provided valuable information by placing each item in context with its surroundings, for example, to understand the possibility of motion and consequences to other items. The proposed approach, although based on observations from residential buildings, is useful for facilities that have sensitive operations, such as offices, industrial facilities, hospitals and government services. As societies become more complex and reliant on non-structural elements, systematic and thorough studies such as the one outlined herein become an increasingly critical part of sound earthquake risk management.
\end{abstract}

Keywords: Risk management; Non-structural damage; South Iceland earthquakes; Residential buildings; Seismic risk.

\section{Introduction}

Homes are a cornerstone of society. Modern residential buildings need to provide safe occupancy and facilitate the general needs of their residents. A home may be unusable due to non-structural damage even when its structure is intact. Non-structural components are those elements that are not designed to carry mechanical loads but are essential in a safe and functional home. These include fixed elements such as architectural, mechanical, electrical, 


\section{Sólveig Thorvaldsdottir et al.}

and plumbing systems and loose components such as furniture and fixtures, broadly called building contents [FEMA, 2011]. These elements are essential for the aesthetics and, more importantly, functionality of modern homes. Apart from loss of functionality, damage and undesirable movement of such elements pose safety hazards to building residents. Therefore, managing non-structural earthquake risk is as important as managing structural earthquake risk. When a significant portion of residential buildings within a given community are severely impacted, the consequences will impact not only the residents and owners, but the community as a whole. Earthquake risk management guidelines for residents are, therefore, of paramount importance for community seismic resilience.

Non-structural elements represent most of the total cost of typical buildings, and a significant portion of the total losses in recent earthquakes worldwide can be attributed to non-structural damages, though the ratios vary between use [Perrone et al., 2019; FEMA, 2011]. Research on earthquake damage has shown the need to improve seismic performance of non-structural elements through regulations. This is important to reduce economic loss, loss of functionality, and threats to life safety [Perrone et al., 2019; Miranda et al., 2012; Dhakal, 2010; Bessason et al., 2016; and Bessason et al., 2014]. The KnowRisk project (https://knowriskproject.com/the-project/) conducted an extensive review of the state-of-the-art of non-structural risk reduction. A key source for non-structural damage and risk reduction measures is FEMA E-74 (revised version 2011), which aims to raise awareness of potential nonstructural risks. FEMA E-74, however, is not intended for homeowners. It refers to FEMA 232 [FEMA, 2006] for information on how to make homes safer from earthquakes. This document provides information on non-structural components such as chimneys, fireplaces, balconies, and decks. Information on safe anchorage of building contents is provided in FEMA E-74 [version 1994].

The National Institute of Standards and Technology published a report [NIST, 2018] outlining performance objectives for non-structural components, an overview of factors contributing to seismic their performance, and an assessment of code requirements focusing in improving clarity, consistency, and enforceability. The NIST report does not distinguish between building use but emphasizes non-structural components and systems that will have the largest impact on public safety and economic welfare. The issue of residential buildings has received limited focus during current developments and the cascading community problems stemming from large scale residential areas seem somewhat overlooked.

In June 2000 south Iceland experienced two earthquakes of Mw 6.5, and in May 2008, a $\mathrm{M}_{\mathrm{w}} 6.3$ event hit the area again. The earthquakes did not cause building collapse or fatalities, but a few people were injured. These earthquakes, however, caused widespread damage to non-structural elements in the epicentral region. The damage was mainly in low-rise residential buildings, which dominate the building stock in the area. Damage to fixed nonstructural components were collected to create two datasets, one for the June 2000 events and one for the May 2008 event. The fixed component dataset is based on insurance claims and compensation estimates. The dataset is complete in the sense that it covers every affected building. The dataset is also very detailed and accurate as the compensation estimates were prepared by qualified engineers. Such complete and detailed databases of seismic damage to residential buildings are rare. A contents dataset covering damage to building contents was also created by analysing photos of damage caused by these events in many homes in. The photos were taken in a few selected houses before the residents started cleaning up. The photos provided an opportunity to do an in-depth analysis of damage to the contents and consider their consequences to other items in their surroundings.

This paper describes how the damage datasets from these earthquakes were used to gain insight into earthquake risk management procedures for residential buildings. Such guidelines need to be based not only on engineering criteria, but also on sound risk-management objectives and principles. More details on such objectives and procedures can be found in Thorvaldsdottir and Sigbjörnsson [2014].

\section{Background Methodology}

\subsection{Disaster Risk Management}

The United Nations International Strategy for Disaster Reduction [UNISDR, 2009] define a disaster as a serious disruption of the functioning of a community or a society involving widespread human, material, economic or environmental losses and impacts, which exceed the ability of the affected community or society to cope using its own resources. Thorvaldsdottir and Sigbjörnsson [2014] turn the UNISDR definition on its head to define a disaster 
resilient community as a "well-functioning community or society with a low risk of serious disruptions involving widespread human, material, economic or environmental losses and impacts to the functioning of a community or a society and to cope with such events using a society's own resources". This generic disaster-related goal can be narrowed to the level of a home where it is well-functioning home with a low risk of serious disruptions involving widespread human, material, economic or environmental losses and impacts to the functioning of a home, and to cope with such events using a home's own resources".

Disaster risk, by definition, is the risk of such an event happening, and disaster risk management is the management of pre-disaster activities. Thorvaldsdottir and Sigbjörnsson [2014] present a theoretical statement stating that: "disaster-related activities aim to understand disaster risk in order to measurably mitigate disaster risk, to prepare for future events associated with any residual unmitigated risk, to intervene in damaging processes and react to lifethreatening situations, to recover from the impact, to provide temporary relief until recovery is accomplished and, finally, learn from the operations in order to improve the system used to meet the objectives." From this statement, Thorvaldsdottir and Sigbjörnsson [2014] derived 8 core objectives needed to meet the disaster-related goal:

1) To understand disaster risk, its components and context (risk analysis)

2) To measurably reduce known disaster risk (risk mitigation)

3) To prepare future operations for dealing with future disasters (preparedness for response)

4) To gain control over damaging processes, such as, intensifying natural processes, collision (impact) of natural processes with elements at risk, and cascading damage.

5) To save the lives of those caught in damaging or otherwise injurious processes

6) To provide temporary relief of suffering to those affected

7) To implement non-temporary measures to return a community to normalcy

8) To systematically learn from the experience of recent events and implement changes

Converting the eight disaster-related objectives into pre-disaster objectives reduces them to four:

1) To understand disaster risk, its components and context

2) To measurably reduce known disaster risk

3) To prepare for the following operations:

a) Operations due to damaging processes

b) Operations that save the lives of those caught in damaging or otherwise injurious processes

c) Operations that provide temporary relief of suffering to those affected

d) Operations that return a community to normalcy

4) To systematically learn from the experience of recent events and implement changes

Deciding how much risk to mitigate and how much to leave to preparedness for response is an iterative process. The more the risk is mitigated the less the need to prepare for response. However, mitigation may be costly and therefore measures are only taken to the extent possible and sensible, thus increasing the need for preparedness for response. A stakeholder (household member in this case) can decide on the extents of mitigation and preparation based on information about costs and benefits of these actions and consequences of inaction. Taking this iterative process into account, pre-disaster risk management can be summarized in the following simplified flowchart (Figure 1).

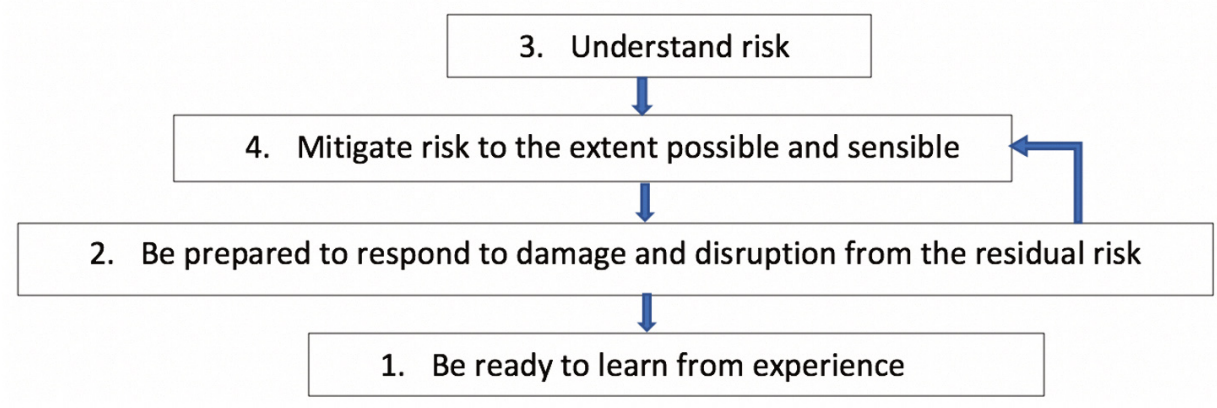

Figure 1. Flowchart for pre-disaster risk management. 


\section{Sólveig Thorvaldsdottir et al.}

\subsection{Damage and Disruption Characterization}

The Damage Ratio (DR), Damage Factor (DF), and Damage States (DS) are often used to characterize damage. The Damage Ratio (DR) is the ratio of the number of buildings damaged to the total number of buildings in the affected area. The Damage Factor (DF) is the ratio of the estimated loss to the replacement value:

$$
\text { DF = Estimated Loss / Replacement Cost }
$$

The estimated loss is the estimated repair cost. The replacement cost could be the building market value or the fire insurance value. A Damage State (DS) describes a given level of damage. Damage states are usually characterized by descriptive words and a short damage description and are sometimes linked to different levels of DFs. The number of DSs in a set from no damage to complete damage, their DF range, and the damage descriptions used, varies depending on issues such as the scope of the study or the data size used for the analysis. For example, ATC [1985] uses seven damage states to describe possible damages to building. The Damage Factor ranges in the ATC Damage States vary from $1 \%$ in DS Slight (0-1\%) up to $40 \%$ in DS Major (60-100\%).

Other examples include one from Colombi et al. [2008] with four DSs: none, slight, significant, and collapse and one form Rossetto and Elnashai [2003] with seven DSs: none, slight, light, moderate, extensive, partial collapse and collapse. In their damage descriptions, Rossetto and Elnashai [2003] associate "slight" with "fine cracks in plaster partitions /infills", whereas Dolce et al. [2006] associate the damage state "slight damage" with DF in the range 0$5 \%$, and "moderate damage" is associated with the DF in the range 5-20\%.

Damage States defined in the literature are usually for structural elements and fixed non-structural elements but exclude building contents. However, damage to contents can seriously impact the operations of a facility, and researchers are beginning to develop Damage States for such items. The notion of disruption is also important when trying to understand the impact to the stakeholder. For example, Pujols and Ryan [2016] used motion (sliding, rocking, toppling, and falling) of different types of items to define five states of disruption for content. Rocking is different from the other categories of motion since it occurs only during the earthquake. By the time damage and disruption is assessed, the object is either back to where it was or has slid, toppled or fallen.

\subsection{Study Area and Seismicity}

The seismicity in Iceland is related to the Mid-Atlantic Plate boundary that crosses the country (Figure 2a). Within the country, the boundary shifts eastward in the south and back toward the west in north Iceland through two complex fracture zones. The southern zone, called the South Iceland Seismic Zone (SISZ), is in the south Iceland lowland, while the other, the Tjörnes Fracture Zone (TFZ), lies mostly off the northern coast of Iceland [Einarsson, 1991]. The largest earthquakes in the country have occurred within these two zones (Figure 2a).

The study area in this research is in the south Iceland lowland, which is the largest agricultural region in Iceland with mountains and highlands to the west, north and east, and a southern coastline (Figure $2 \mathrm{~b}$ ). The region holds several farms, small towns and villages, schools, medical centres, industrial plants, and all infrastructure that characterises modern society. The population was about 18,500 inhabitants in January 2008 and there were approximately 6,000 residential houses. All buildings are registered in a detailed official property database [Registers Iceland, 2002]. The SISZ crosses the region, and since 1700, there have been 16 earthquakes of magnitude six or larger in the area [Halldórsson et al., 2013]. The largest one of these was of magnitude 7.0 in 1912.

The first seismic hazard map was presented in Iceland in 1958 [Tryggvason et al. 1958], and the map had some influence on contemporary seismic design. (low code). The first official seismic design code was implemented in 1976 (moderate code) (ÍST 13, 1976), and in 2002 the Eurocode 8 (high code) was introduced [SI, 2002]. The present seismic hazard map for Iceland, given in the national annexes for Eurocode 8, show PGA=0.5g (g representing acceleration due to gravity) in the epicentral zone (Figure 2a) of the study area [SI, 2010]. The probability of exceeding this value is $10 \%$ in 50 years (475-year mean return period). All the main villages in the SISZ in Figure 2b (Selfoss, Hveragerði, Thorlákshöfn, Hella and Hvolsvöllur) are in the 0.5g zone, while the corresponding PGA value for the greater Reykjavik capital region is $0.2 \mathrm{~g}$ or lower. 

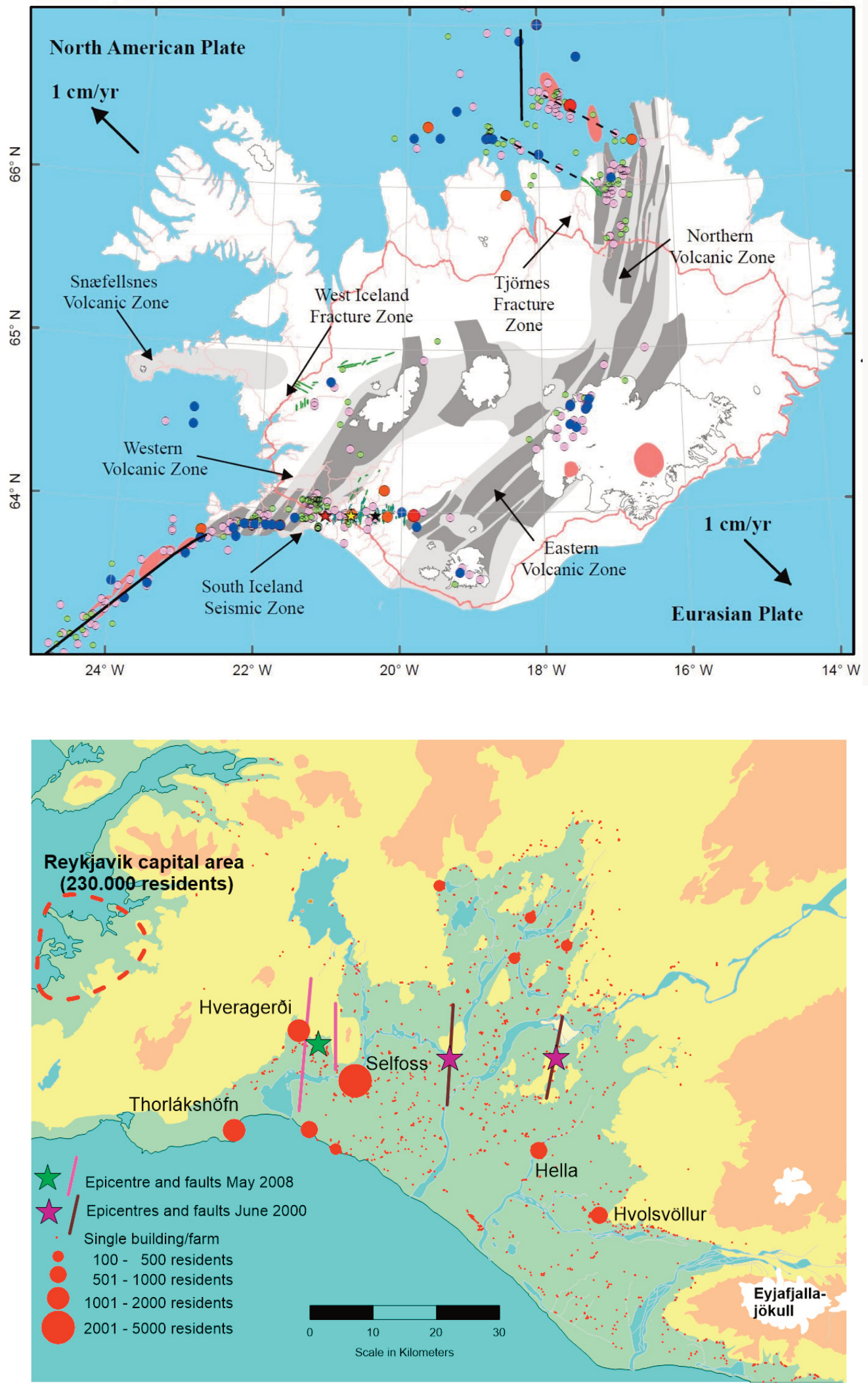

b)

Figure 2. A map of Iceland showing main tectonic and geologic features is shown in Figure 2a. The circles represent epicentres of past earthquakes since 1896. The pink dots show earthquakes in the range 4-5, blue in the range 5-6, orange in the range 6-7 and red $>7$. The study area in the South Iceland Seismic Zone is shown in more detail in the bottom map. The red dots in Figure $2 \mathrm{~b}$ represent buildings, farms, and settlements, whose sizes are indicated in the legend. 


\section{Sólveig Thorvaldsdottir et al.}

\subsubsection{Earthquakes and Damages}

In June 2000, two earthquakes of $M_{w} 6.5$ struck in the SISZ (Figure 2b). The first struck on June 17, 2000, 15:41, (GMT) in the eastern part of the area. It was a right-lateral strike-slip quake, with fault striking in the north-south direction and had a focal depth of $6.3 \mathrm{~km}$. The second earthquake, struck on June 21, 2000, at 00:52, (GMT) further west. It was also a right-lateral strike-slip earthquake, with the fault striking in the north-south direction and a focal depth of $5.3 \mathrm{~km}$. The highest recorded PGA in these two events was 0.84g [Thorarinsson et al., 2002].

In May 2008, the third earthquake of this century struck the area. It consisted of two ruptures on nearby faults. The first rupture occurred on the eastern fault west of the town Selfoss that triggered a rupture on the western fault, about one second later (Figure $2 \mathrm{~b}$ ). The magnitude of the combined event has been computed to be $\mathrm{M}_{\mathrm{w}} 6.3$. In Hveragerdi and Selfoss, horizontal Peak Ground Acceleration (PGA) as high as $0.66 \mathrm{~g}$ and $0.54 \mathrm{~g}$ were recorded, respectively, by the Icelandic Strong Motion Network [Halldórsson and Sigbjörnsson, 2009; Sigbjörnsson et al., 2009; Rupakhety et al., 2016].

\section{Damage datasets}

\subsection{Architectural, mechanical, electrical, and plumbing systems (Insurance loss dataset)}

Two complete and detailed insurance loss datasets exist for the study area, one collected after the two $\mathrm{M}_{\mathrm{w}} 6.5$ south Iceland earthquakes of June 2000 and another after the $\mathrm{M}_{\mathrm{w}} 6.3$ south Iceland earthquake of May 2008. The data was collected by the Natual Catastrophe Insurance of Iceland [2020]. The datasets include losses of both structural and non-structural elements. The non-structural losses only cover fixed non-structural elements (architectural, mechanical, electrical, and plumbing systems) but not damage to building contents. The loss data from the two June 2000 earthquakes was classified into five subcategories, two for structural loss and three for non-structural loss. The loss data from the May 2008 event is more detailed and was split in 10 subcategories, five for structural losses and five for non-structural losses. More details on the datasets can be found in Ferreira et al., [2020], Bessason and Bjarnason [2016], and Bessason et al. [2014]. The loss data from the 2000 events has been used to develop advanced empirical vulnerability models for the total losses, i.e., the sum of both structural and non-structural losses, [Bessason et al., 2020; Ioannou et al., 2018].

In this study the focus is on non-structural losses. The subcategories for non-structural elements in the 2000 events (I, II and III) and the 2008 earthquake (1, 2, 3, 4, and 5) are shown in Table 1. Subcategory I and 1 are identical in both the datasets. Subcategory II for the 2000 dataset is equivalent to the subcategories 2, 3 and 4 from the 2008 dataset. Finally, subcategory III in the 2000 loss dataset corresponds to subcategory 5 in the 2008 dataset.

Losses due to interior fixtures, paintwork, flooring, wall tiles, windows, doors, etc. has the highest prevalence, see subcategory II in Table 1. However, damage due to plumbing, radiators, and electrical installations was low in in all building types.

\begin{tabular}{ccl}
$\begin{array}{c}\text { Subcategories in the } \\
\text { 2000 loss dataset }\end{array}$ & $\begin{array}{l}\text { Subcategories in the 2008 } \\
\text { loss dataset }\end{array}$ & $\begin{array}{l}\text { Description } \\
\text { I }\end{array}$ \\
\hline & 1 & $\begin{array}{l}\text { Interior finishing work (partition walls, mortar, } \\
\text { suspended ceilings, cladding }\end{array}$ \\
\hline 2 & $\begin{array}{l}\text { Interior fixtures, incl. kitchen and bathrooms, doors, } \\
\text { flooring, wall tiles etc. }\end{array}$ \\
\hline II & 3 & $\begin{array}{l}\text { Windows, glass, exterior doors, wall cladding } \\
\text { III }\end{array}$ \\
\cline { 2 - 3 } & 4 & $\begin{array}{l}\text { Paintwork outdoors and indoors, including crack } \\
\text { filling and surface treatment }\end{array}$ \\
\hline 5 & $\begin{array}{l}\text { Plumbing (cold water, hot water and sewer pipes), } \\
\text { radiators, electrical installations }\end{array}$ \\
\hline
\end{tabular}

Table 1. Subcategories of non-structural element losses observed in the 2000 earthquakes (column 1) and in the 2008 earthquake (column 2). 


\subsection{Building contents (EERC photo dataset)}

The building content damage dataset was collected by the Earthquake Engineering Research Centre (EERC) via site visits and telephone interviews in the wake of the 2000 and 2008 earthquakes. It consists of photographs and completed questionnaires in paper form. This dataset is called the EERC data set. Most of the data are from singlefamily dwellings. The interviewees were usually both the owners and occupants of the buildings. The interviews took place between 2000-2004 for the 2000 earthquakes, and in 2008 for the 2008 earthquake. The dataset for the 2000 is considerably larger and is separated into the $200017^{\text {th }}$ June and the $21^{\text {st }}$ June earthquakes. The interviewees were asked about their experiences with the earthquake, the movement of building contents, damage to the building, both structural and non-structural, and damage outside the building.

At the time of the 2000 earthquakes, approximately 15,000 people lived in about 5,000 houses in the two counties of the study area, Árnessýsla and Rangárvallasýsla. It was estimated that the most impacted area had 2,400 houses and 5,000 people. The survey covered 168 houses and 180 people, and sometimes more than one person from the household was interviewed. The 168 houses were chosen to include a wide distribution of geographical location, age, and construction material and type of the dwellings. A few houses were included due to their closeness to the epicentre or causative fault and because they housed the EERC strong motion accelerometers. Photographs are only available from some of the houses covered in the survey.

Based on an initial analysis of the dataset, it was decided to use only the photographs for the study as they gave more information than the answers in the questionnaires. The investigation of the EERC dataset led to a set of photographs of 26 buildings from 17 sites, 16 sites that were damaged during the 2000 earthquakes, and one site from the 2008 earthquake that was usable for the analysis (Table 2).

\begin{tabular}{|c|c|c|c|c|c|}
\hline $\begin{array}{l}\text { Site } \\
\text { Id }\end{array}$ & $\begin{array}{l}\text { Construction } \\
\text { Year }\end{array}$ & Material & Soil Class & $\begin{array}{l}\text { Fault distance } \\
(\mathbf{k m})\end{array}$ & $\begin{array}{l}\text { PGA } \\
\text { (g) }\end{array}$ \\
\hline 1 & 1975 & $\mathrm{RC}$ & A & 1.5 & 0.85 \\
\hline \multirow[t]{2}{*}{2} & 1997 & Timber & $\mathrm{A}$ & 4.8 & 0.43 \\
\hline & 1958 & Masonry & $\mathrm{A}$ & 4.9 & 0.42 \\
\hline \multirow[t]{2}{*}{3} & 1959 & $\mathrm{RC}$ & A & 3.1 & 0.61 \\
\hline & 1999 & Timber & A & 3.1 & 0.61 \\
\hline 4 & 1970 & $?$ & $\mathrm{~A}$ & 12.4 & 0.16 \\
\hline \multirow[t]{2}{*}{5} & 1978 & $\mathrm{RC}$ & A & 6.3 & 0.33 \\
\hline & 1996 & Timber & A & 6.2 & 0.34 \\
\hline \multirow[t]{2}{*}{6} & 1956 & $\mathrm{RC}$ & A & 4.3 & 0.47 \\
\hline & 1986 & Timber & $\mathrm{A}$ & 4.3 & 0.47 \\
\hline 7 & 1966 & $\mathrm{RC}$ & A & 1.3 & 0.89 \\
\hline 8 & 1991 & Timber & A & 5.2 & 0.40 \\
\hline 9 & 1976 & $\mathrm{RC}$ & $\mathrm{A}$ & 3.1 & 0.60 \\
\hline 10 & 1946 & $\mathrm{RC}$ & B & 8.0 & 0.34 \\
\hline 11 & 1958 & $\mathrm{RC}$ & A & 1.1 & 0.92 \\
\hline \multirow[t]{2}{*}{12} & 1930 & $\mathrm{RC}$ & $\mathrm{A}$ & 1.1 & 0.92 \\
\hline & 1981 & Timber & $\mathrm{A}$ & 1.1 & 0.92 \\
\hline \multirow[t]{2}{*}{13} & 1960 & $\mathrm{RC}$ & A & 1.8 & 0.80 \\
\hline & 1995 & Timber & A & 1.8 & 0.80 \\
\hline 14 & 1960 & $\mathrm{RC}$ & $\mathrm{A}$ & 0.1 & 1.01 \\
\hline \multirow[t]{2}{*}{15} & 1950 & $\mathrm{RC}$ & $\mathrm{A}$ & 0.6 & 0.98 \\
\hline & 1961 & $\mathrm{RC}$ & $\mathrm{A}$ & 0.7 & 0.97 \\
\hline \multirow[t]{2}{*}{16} & 1981 & Timber & $\mathrm{A}$ & 0.3 & 1.00 \\
\hline & 1991 & Timber & A & 0.8 & 0.96 \\
\hline \multirow[t]{2}{*}{17} & 1990 & Timber & A & 0.90 & 0.95 \\
\hline & 1984 & Timber & $\mathrm{A}$ & 0.99 & 0.93 \\
\hline
\end{tabular}

Table 2. Site and building information where photographs were taken. In many cases two buildings were at the same site. 


\section{Sólveig Thorvaldsdottir et al.}

Most of the buildings were permanent homes and five were seasonal residences called summerhouses. Most of them were one storey, but some were two storeys. The sites of the photographed building are listed in Table 2 along with shortest distance to fault and Peak Ground Acceleration (PGA) based on the attenuation equation of Rupakhety and Sigbjörnsson [2009]. Thirteen sites out of seventeen were located where the fault distance was less than $5 \mathrm{~km}$. When compared to Figure $2 b$, it is clear that the sites were not randomly picked. They were generally buildings where the disruption was extensive and the owner wanted photographs. In cases where the damage was limited, the owners usually did not take photographs. This means that the photos are biased and cannot be used to make any damage statistics. They are, nevertheless, informative as they show types of damage to non-structural elements and the disruption the damage caused during the earthquakes in context with their surroundings.

A total of 309 photos taken in 26 buildings were analysed. The photos did not cover every room in every house, but rather seem to have been taken based on where damage occurred. Table 3 lists the number of rooms of different types identified in the photographs. Most of the photographs are from living rooms, kitchens, and bedrooms or offices. Bedrooms and offices were combined into one category as it was not always easy to separate between the two. Some rooms only had one photo, while other rooms had more. Seven photos that could not be associated with a room type were not used.

\begin{tabular}{ll} 
Room type & Number of rooms \\
\hline Living room & 22 \\
\hline Kitchen & 21 \\
\hline Bedroom/office & 20 \\
\hline Children's bedrooms & 15 \\
\hline Larder and laundry & 13 \\
\hline Corridor and TV room & 13 \\
\hline Bathroom & 13 \\
\hline Garage & 11 \\
\hline Master bedrooms & 10 \\
Total & $\mathbf{1 3 8}$
\end{tabular}

Table 3. Room types and number of rooms from 26 buildings.

Some examples of photos from the EERC dataset are presented in Figure 3. The photos are from separate rooms in the same house.

\section{Analysis of damage data}

\subsection{Architectural, mechanical, electrical, and plumbing systems (Insurance loss data set)}

Analyses of the insurance loss data [Bessason et al., 2014; Bessason et al., 2016; Ferreira et al., this issue] show that fixed non-structural components are more vulnerable than structural elements in all the building types affected by the three earthquakes. For the $\mathrm{M}_{\mathrm{w}} 6.5$ June 2000 events, the ratio of non-structural damage to total damage was in the range of $60-70 \%$, whereas it was in the range of $80-90 \%$ for the $\mathrm{M}_{\mathrm{w}} 6.3$ May 2008 event. The seismic energy released in each of the two earthquakes in June 2000 is about twice that released in the May 2008 earthquake. This difference in seismic energy is potentially one of the reasons for lesser structural damage in the May 2008 event. The ratios of non-structural to total damage reported above are average numbers for all the affected buildings. However, if only buildings close to the fault rupture (PGA>0.20g) are studied for the June 2000 events, the ratios are less than $50 \%$, pointing out that the structural losses were higher than the non-structural losses for these buildings. 


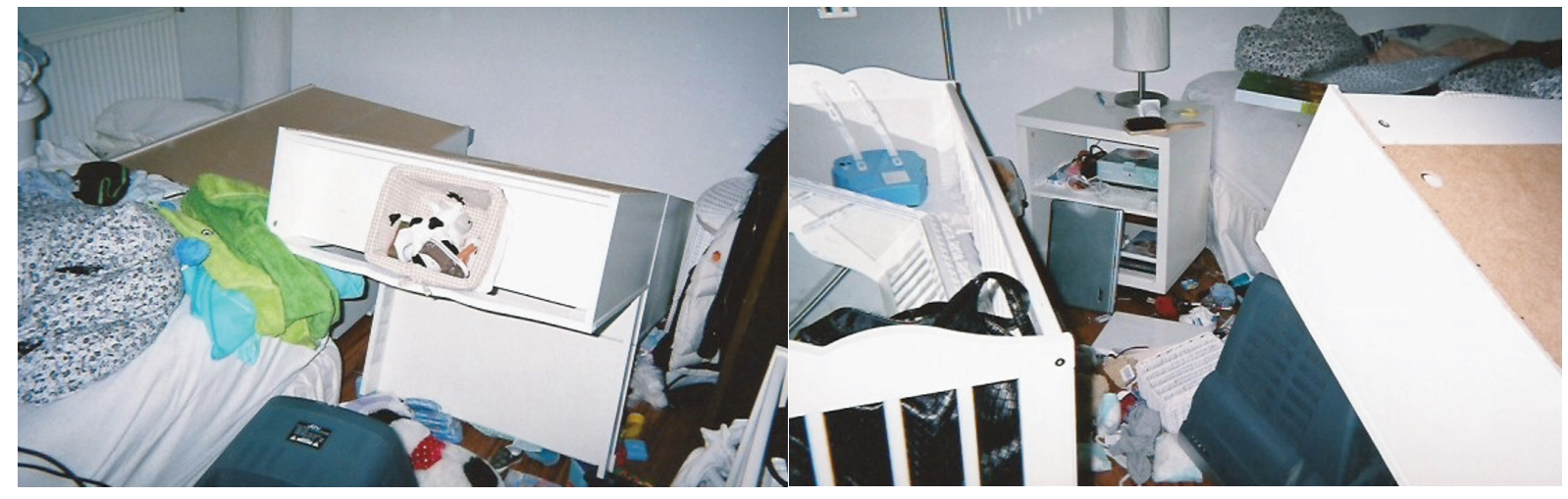

a) Master bedroom

b) Master bedroom

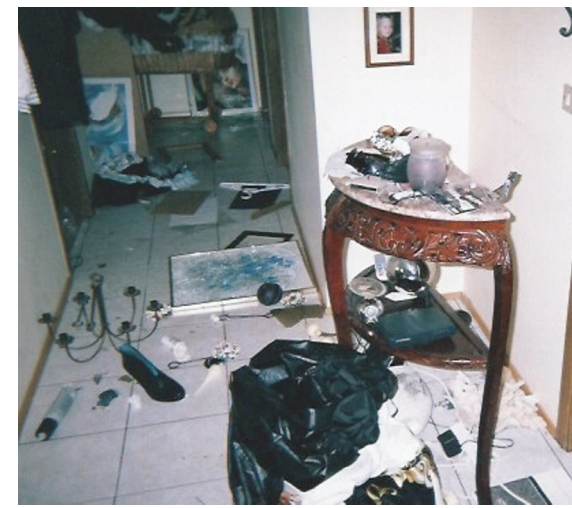

c) Corridor

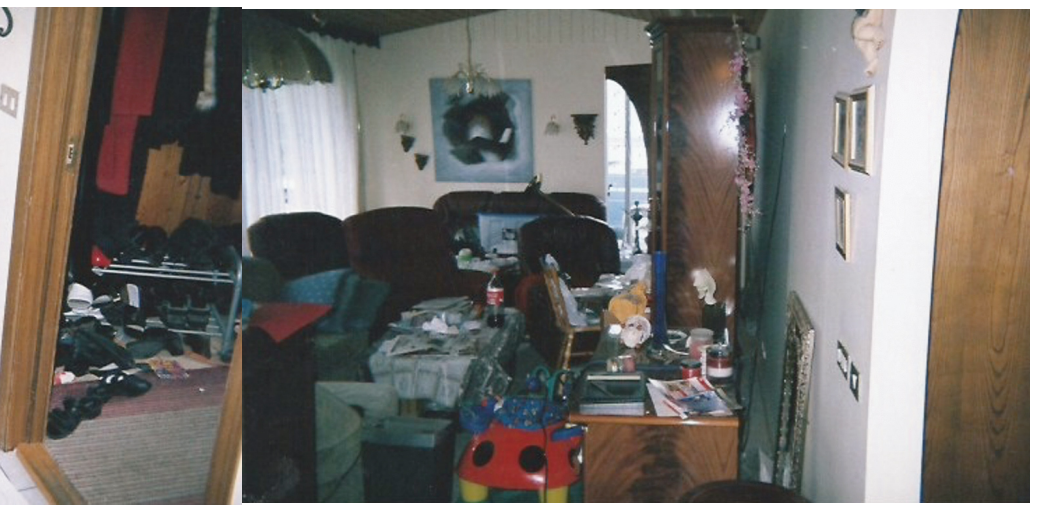

d) Living Room

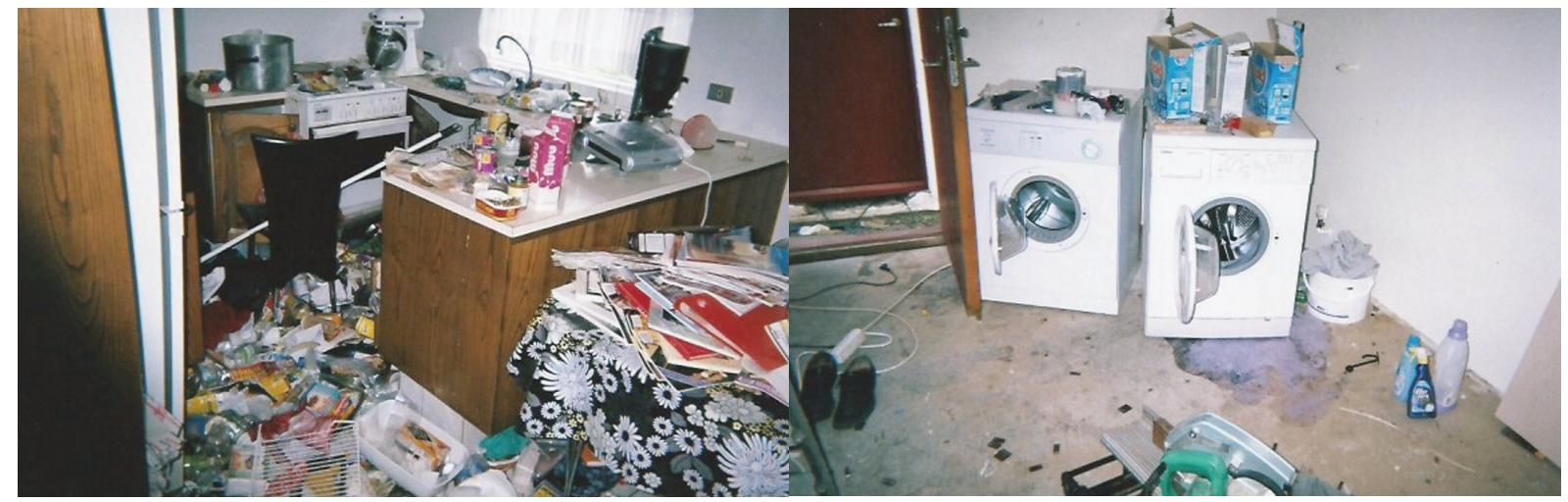

e) Kitchen

f) Laundry room

Figure 3. Examples of non-structural damage in different rooms of a residential building caused by the June 2000 earthquake in south Iceland.

Elements in subcategory II (Table 1) were the most frequently damaged non-structural components, comprising of $70-90 \%$ of total non-structural damage. Most frequently damaged elements in the May 2008 event are from subcategories 2 and 4 (Table 1). In subcategory 2, cosmetic damage to flooring is the most frequent damage. This is mostly caused by objects falling on the floor and by furniture such as bookshelves rolling. In subcategory 4 , most of the damage was related to cosmetic damage of interior walls that required crack filling and indoor paintwork [Bessason et al., 2014]. On the other hand, interior finishing work (partition walls, mortar, suspended ceilings, cladding) as well as plumbing (cold water, hot water and sewer pipes), radiators, and electrical installations performed well in general. 


\section{Sólveig Thorvaldsdottir et al.}

\subsection{Building content (EERC photo dataset)}

The initial objectives of the analysis of the EERC photo data are:

1) Identify the type of items (typical items) found in each room type,

2) Study the types of motion the items succumbed to due to the earthquake,

3) Estimate replacement cost, and

4) Study the effects the motion had on the functionality of the items.

The analysis of the initial objectives led to further investigation of the impact based on the context and surroundings depicted in the photo. The following questions were then asked.

1) What were the consequences of the loss of function of that item?

2) What type of secondary impact (damage) could the motion cause?

Finally, the following questions linked to risk management were studied.

1) What type of mitigation action could have prevented the motion?

2) What type of response would be required, or could be performed, to negate/dampen the effects of the motion (impact response)?

3) What type of response (rescue, relief and/or recovery) would be required due to the motion of the item or its consequences?

To structure the direct and inferred data in a logical order, the tabular format shown in Figure 4 was developed. The logical progression is from identifying the item (column 1), to understanding the physical impact, to consequences, to suggested mitigation, and if mitigation fails, what response is required (columns 14-17).

\begin{tabular}{|c|c|c|c|c|c|c|c|c|c|c|c|c|c|c|c|c|}
\hline \multirow[t]{2}{*}{ ITEMS } & \multicolumn{3}{|c|}{ MOTION } & \multicolumn{2}{|c|}{ PHYSICAL DAMAGE } & \multicolumn{4}{|c|}{ CONSEQUENCES } & \multirow{2}{*}{$\begin{array}{c}\text { SECONDARY IMPACT } \\
\text { TO OTHER ITEMS } \\
\text { AND PEOPLE } \\
\end{array}$} & \multirow{2}{*}{$\begin{array}{l}\text { MITIGATION } \\
\text { CATEGORY }\end{array}$} & \multirow{2}{*}{$\begin{array}{l}\text { MITIGATION } \\
\text { ACTION }\end{array}$} & \multicolumn{4}{|c|}{$\begin{array}{c}\text { DISASTER ACTIVITIES REQUIRED, if } \\
\text { no mitigation is performed }\end{array}$} \\
\hline & Slide & Topple & Fall & RC & Functionality & Human & Natural & Economic & Social & & & & Impact & Rescue & Relief & Recovery \\
\hline \multicolumn{17}{|c|}{ Sub Categories } \\
\hline & & & & & & & & & & & SECURE & & & & & \\
\hline & & & & & & & & & & & PROTECT & & & & & \\
\hline & & & & & & & & & & & MOVE & & & & & \\
\hline & & & & & & & & & & & Nothing & & & & & \\
\hline \multicolumn{17}{|c|}{ Sub Categories } \\
\hline & & & & & & & & & & & & & & & & \\
\hline
\end{tabular}

Figure 4. Direct and inferred data table format for the EERC photo data analysis.

\section{Column 1: Items typically found in each room type}

Typical building content for each room in the study area was identified from the photos and listed in column 1. The "items" can be a single item (e.g., a sofa), a group of similar items (e.g., dishes), or elements of an item (e.g., doors, shelves, drawers and frames that together make a cabinet). Not every house had all items, but the list was compiled to provide an overview of typical items in a home. The items in each room were then divided into three to seven subcategories depending on the number of items in the room based on similarity in their functions or expected behaviour, therefore requiring similar mitigation measures, which allowed them to be placed in the same mitigation group. The categories and subcategories for each room are presented in Figure 5. Items found in a summerhouse that are also common in homes were not listed as special items. However, items that are not common in homes but are common in summerhouses were listed as "Summerhouse extras". A total of 196 item types were identified, divided into 7 rooms (Figure 6). 
Non-Structural Seismic Risk Management

\begin{tabular}{|c|c|c|c|}
\hline KITCHEN (41) & BEDROOM AND OFFICE (41) & LIVINGROOM (31) & CORRIDOR/TV (30) \\
\hline Appliances in cabinet & Fixtures & Fixtures & Fixtures \\
\hline Oven & Cupboard boxes & Light fixtures on walls & Light fixtures on walls \\
\hline Microwave & Shelves, wooden & heaters on walls & heaters on walls \\
\hline Fridge & Curtain rods & Individual shelves & Mirror \\
\hline Dishwasher & Cupboards doors & Cupboard boxes & Curtain rods \\
\hline Stove & Light fixtures & Doors on cupboards & Furniture \\
\hline Fixtures & Door & Furniture & Cupboard boxes \\
\hline Cabinet box & Cabinet draws & Piano & Bookshelves \\
\hline Cabinet shelves & Appliances & Bookshelves & Chest of draws \\
\hline Cabinet doors, pull & TV & Sofa & Tables on wheels \\
\hline Curtain rods & Computers, monitors, laptops & Sofa chairs & Doors on cupboards \\
\hline Cabinet doors, slide & Keyboard, speakers & Dining room table & Chairs \\
\hline Cabinet draws & Printers & Sofa table & Sofa \\
\hline Sink & Stereo & Dining room chairs & Sofa table \\
\hline Fans over stove & Video player & Appliances Loose & Table \\
\hline Hanging objects & Record player - turntable & TV & Benches \\
\hline Pictures & Sewing machine & Stereo/speakers & Appliances \\
\hline Clocks & Lamps & Video & TV \\
\hline Heater & Content, should be protected & Table lamps & Telephone \\
\hline Light fixtures & Boxes & Floor lamps & Fax machine \\
\hline Heavy content not in cabinet & Statues, memorabilia & Hanging objects & Lamps \\
\hline Flower pots & Items hanging on walls & Hanging lights & Hanging items \\
\hline Wine bottles racks & Ceramic items & Glass picture frames & Hanging lights \\
\hline Knife racks & Breakables & Content on shelves or tables & Pictures \\
\hline Medicine cabinet & Flower pots & Candlesticks & Memorabilia \\
\hline Fishbowl & Musical instruments and cases & Statues & Content \\
\hline Appliances Loose & Tables on wheels & Flower pots & Clocks \\
\hline Kettle & Cupboards & Memorabilia & Books \\
\hline Coffeemaker & Bookshelves & Books & Candlesticks \\
\hline Toaster & Shelves & Silver items & Vases \\
\hline Mixer & Tables on wheels & Clocks & Flower pots \\
\hline Blender & Beds & Content, breakables & Ceramic items \\
\hline In cabinet, fridge, dishwasher & Sofas & Vases & Drinking glasses \\
\hline Food & Tables & Glass frames & Shoes \\
\hline Cutlery & Chairs & Nice coffee set & Ironing board \\
\hline Pots and pans & Desks & Nice dishes, bowls & \\
\hline Tupperware & Content, that is generally loose & Nice wine glasses & \\
\hline Rubbish in bins & Wine bottles & & \\
\hline Content, Breakables & Books, folders, papers & & \\
\hline Dishes and bowls & Bottle top collection & & \\
\hline Mugs, Cups, Glasses & CDs, cassettes, videos & & \\
\hline Jars, Bottles & Suitcases & & \\
\hline Ceramic objects & Records & & \\
\hline Eye glasses & Photo albums & & \\
\hline Spice bottles & Toys & & \\
\hline Furniture & Clothes & & \\
\hline \multicolumn{4}{|l|}{ Tables } \\
\hline \multicolumn{4}{|l|}{ Chairs } \\
\hline Highchair & & & \\
\hline
\end{tabular}

\begin{tabular}{|c|c|c|c|}
\hline LARDER_LAUNDRY (20) & BATHROOM (15) & GARAGE AMD STORAGE (13) & SUMMERHOUSE EXTRA (5) \\
\hline Appliances & Fixtures & Maintenance & Additional items \\
\hline Washing machine & Cupboard boxes & Cupboards & Fire place \\
\hline Dryer & heaters on walls & Gym equipment & Paraffin oil stove \\
\hline Freezer & Doors on cupboards & Boxes storing household items & Wood for burning \\
\hline Fixtures & Mirror & Empty bottles & Bench \\
\hline Fixed shelves & Curtain rods & Household items in storage & $\begin{array}{l}\text { Rocking chair } \\
\end{array}$ \\
\hline Water tank & Cupboards draws & Outdoor equipment & \\
\hline Light fixtures & Toilet & Tools & \\
\hline Mostly on shelves or cabinets, large & Bathtub & Tool boxes & \\
\hline Fire extinguishers & Glass shower curtain & Generator & \\
\hline Toolbox & Appliance & Oils and chemicals & \\
\hline Storage boxes & Washing machine & Wheel barrow & \\
\hline Paint & Content, loose & Boxes & \\
\hline Ice chests & Flower pots & BBQ equipment & \\
\hline On shelves or cabinets, small & Ceramic items & Camping equipment & \\
\hline Food & Toiletries/Make up & Skis & \\
\hline Breakables & Cleaning chemicals & & \\
\hline Wine bottles & Mugs, Cups, Glasses & & \\
\hline Baskets & & & \\
\hline Washing powder/liquid & & & \\
\hline Shoes & & & \\
\hline Umbrella & & & \\
\hline Overcoats & & & \\
\hline Folders/Papers & & & \\
\hline
\end{tabular}

Figure 5. Main and subcategories of items identified in each room type. 


\section{Sólveig Thorvaldsdottir et al.}

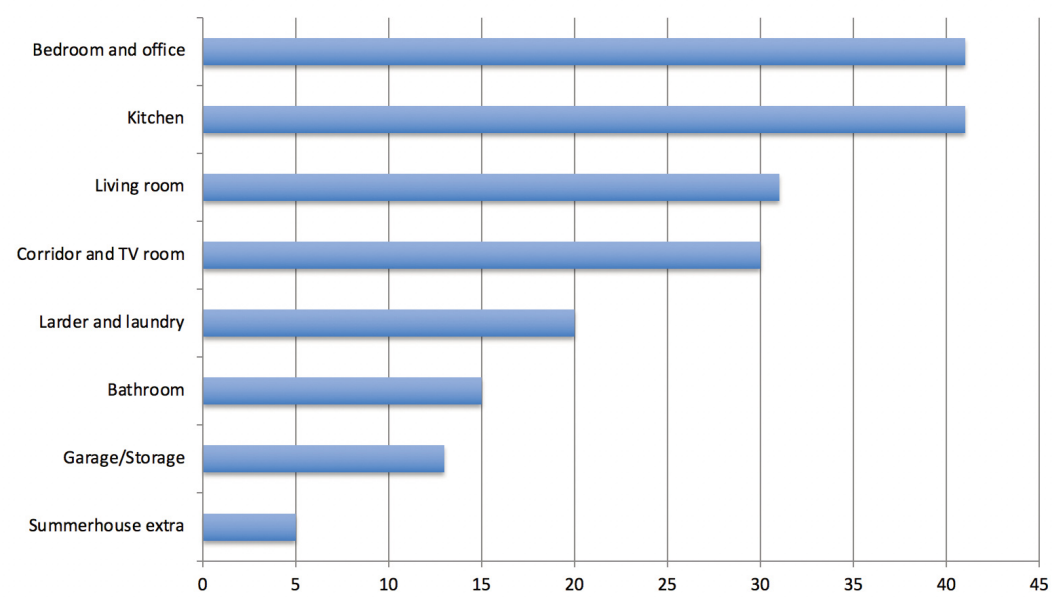

Figure 6. Number of items per room type.

It became apparent that the level of damage and disruption observed is proportional to the number of items in the room. Kitchens and bedrooms/offices contained the most items ( 41 in each). The general opinion of the residents from the EERC survey was that most of the damages occurred in the kitchen, and this was confirmed through the data. Figure 7 shows examples of extensive disruption in kitchens after the south Iceland earthquakes of June 2000 and May 2008.

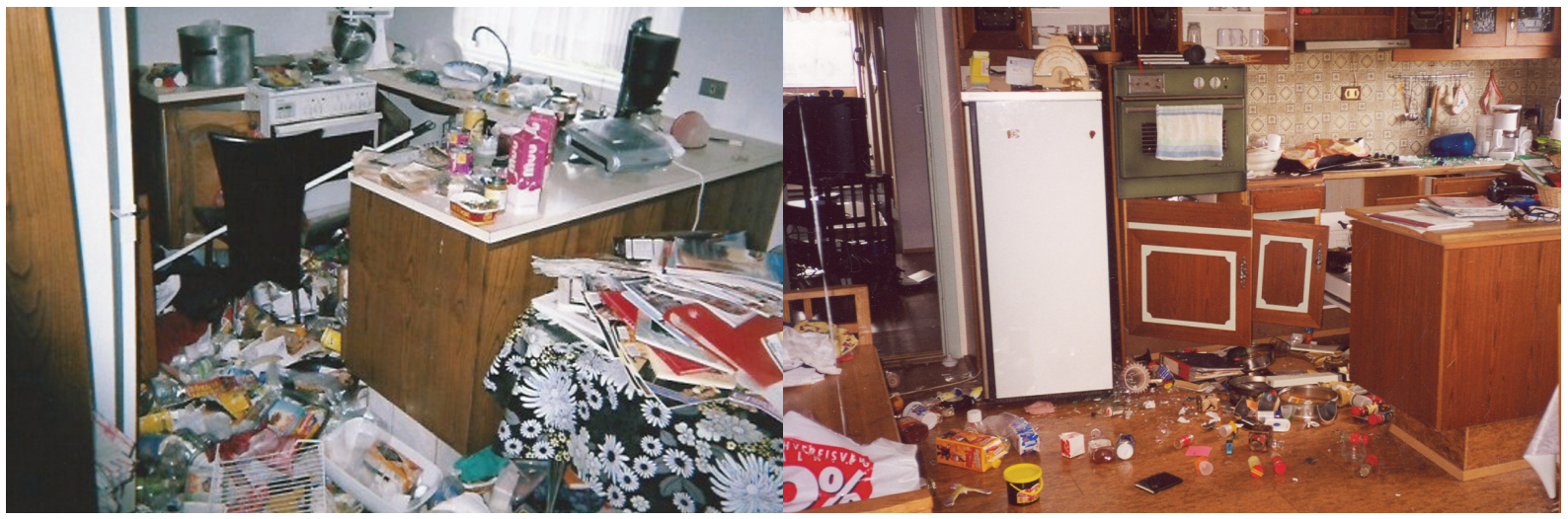

a) Example 1

b) Example 2

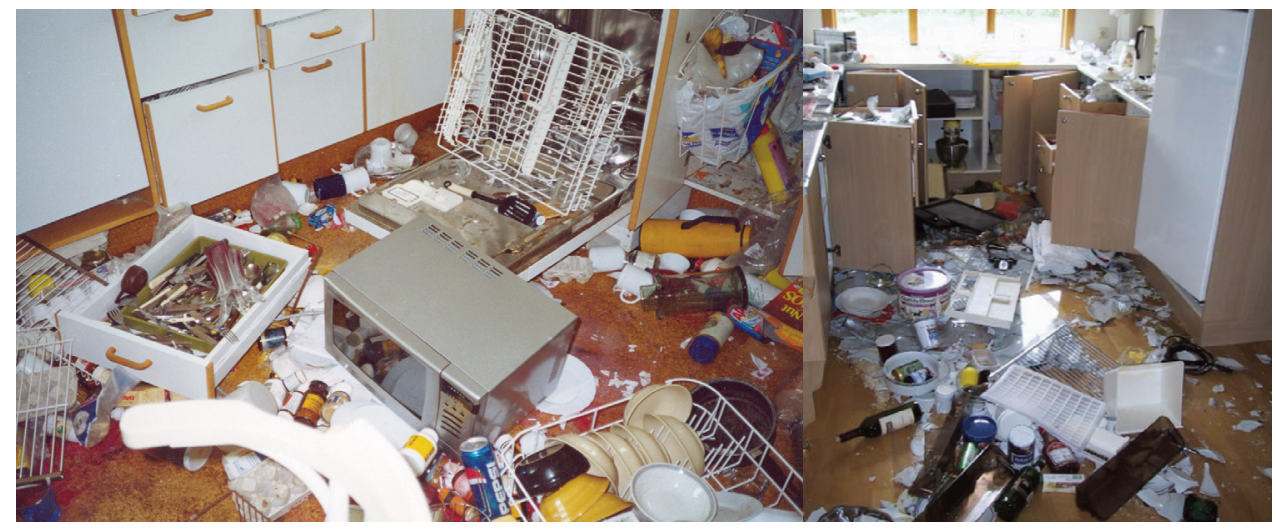

c) Example 3

e) Example 4

Figure 7. Damage in kitchens in four different buildings during the south Iceland earthquakes of June 2000 and 2008 (EERC data set). 
Bathroom and garages/storage have the least of items. However, the items in the bathroom are considerably smaller than those in the garage/storage. Therefore, a count is not enough to get an understanding of the variety of items in the rooms.

\section{Columns 2-4: Motion of items}

Each item can move to a final state of damage in the following ways:

- Slide (horizontal): this includes doors attached at hinges

- Topple (rotational): falling over

- Falling (vertical): this requires sliding or toppling to happen first. Also, the item must be located above the floor.

The label of Motion in Figure 4 was split into the three sub-labels: slide, topple, and fall. This field is marked 1 for yes, and 0 for no based on an analysis of the photos. If an item could in any home sustain sliding, toppling, or falling motion, then the field was marked "yes", even though it was not the case in all homes. Therefore, the tables represent what could happen based on these photos, not what happened in every case. Also, only motion observed was marked, e.g., tables and chairs were only marked as able to slide (they cannot fall as they are already on the floor) as none of the photos showed toppled chairs. This does not mean that tables and chairs have not been toppled in other earthquakes.

\section{Columns 5-6: Physical damage}

The column for physical damage is divided into two parts.

- Repair cost: In this study, item repair cost was not obtained, so the column is blank. Replacement cost (buying a new item) is easily obtained in any study area to give a maximum value for a repair cost.

- Level of functionality: The column is designed to show the function level (Full function, Reduced function, Destroyed with no remaining function). As the photos do not always give complete information on damage for example, a toaster that fell on the floor may or may not be still usable, a description of a fully functioning item was given. The column reflects the usage of the room.

\section{Columns 7-10: Consequences}

Four types of consequence categories were considered, based on the asset categories used in the Livelihood Sustainable Framework [DFID, 1999].

- Human: Blocked passages hindering access, injury due to being hit by projectiles and cuts due to walking on broken items

- Natural: No photo showed harmful impact on the natural environment, therefore this was not included in this study

- Economic: Estimated to be low for each individual item, and therefore not considered in the study

- Social value: Practical (cabinets, toasters, tables, and chairs), emotional (photos, memorabilia), essential (food, toilet), and optional (spices)

\section{Column 11: Secondary impact}

Two types of secondary impact were considered.

- Damage that items cause to other items 


\section{Sólveig Thorvaldsdottir et al.}

- Injury that items inflict on people

Secondary damage and injuries highlight how objects that are projected across a room can damage items, such as flooring and kitchen counters. Food and wine can leave stains on furniture, and shattered glass can scratch items and cut people who are cleaning up the debris.

\section{Column 12: Mitigation Category}

The mitigation categories are as follows:

- Move

- Protect

- Secure

- Retrofit

- Nothing

The first four mitigation categories used in this study are those used in the KNOWRISK Practical Guide. The definition of "Move" in the KNOWRISK Practical Guide is to move an item one time, i.e., move a bed away from a window. Here, the move category was expanded to mean not only move once permanently, but to move it after every use to a secure location, e.g., placing kitchen items in a cupboard with secured doors. "Protect" is to protect fragile or expensive items from falling using inexpensive and easy to apply materials. "Secure" applies to large and heavy items that can pose a danger when loose, using more durable solutions than in the protect category. "Retrofit" involves more specialized knowledge and usually requires the resident to call upon expert advice from engineers or architects. The retrofit category was only used for fixed non-structural items, not loose items.

A new category of "Nothing", was added after studying the photos, as it seemed obvious that some items will not be protected, secured, or moved. They will simply be placed in the room where they best fit, such as a kitchen table, a sofa, or a lamp. It is important to be aware of the items that are loose.

\section{Column 13: Mitigation Action}

The mitigation actions used to fill in Figure 4 were determined by analysing the photos and information in the preceding columns. Damage and the threat of damage to household items are related to the item's ability to move, i.e., slide, topple and fall. In most cases, it is possible to perform some type of mitigation action (secure, protect, and/or move items) to increase indoor safety and to reduce losses. In some cases, it may be impractical to take actions such as fastening sofas, dining room tables, and kitchen items that are frequently used. As mitigation actions were assigned, a pattern of similar actions began to emerge. These actions were then grouped to create mitigation categories. The list of resulting mitigation categories is shown in Figure 8 along with the number of times that category was assigned. Note that the actions are not mutually exclusive. For example, one category is to place an item behind baby locked doors, while another is to baby lock doors, so the former assumes that the latter is implemented. The most common is the most logical option, which is to prevent the object from moving. This implies a freestanding object. No action at all is the second largest category. This is an important result that emphasizes preparedness, since not all risk can, or will, be mitigated. The third most common is to prevent something from opening, implying a cabinet of some sort. The action to put items in a secure place when not in use can be difficult to sustain as it involves repeated actions opposed to, for example, fixing a bookshelf to a wall once.

Figure 9 shows the frequency of mitigation actions per room type. For most rooms, "Protect" is the main option available. However, in the kitchen and larder/laundry room it is important that residents put things away after use. Since "Move" and "Protect" are the cheaper options, they should be easy to implement. 


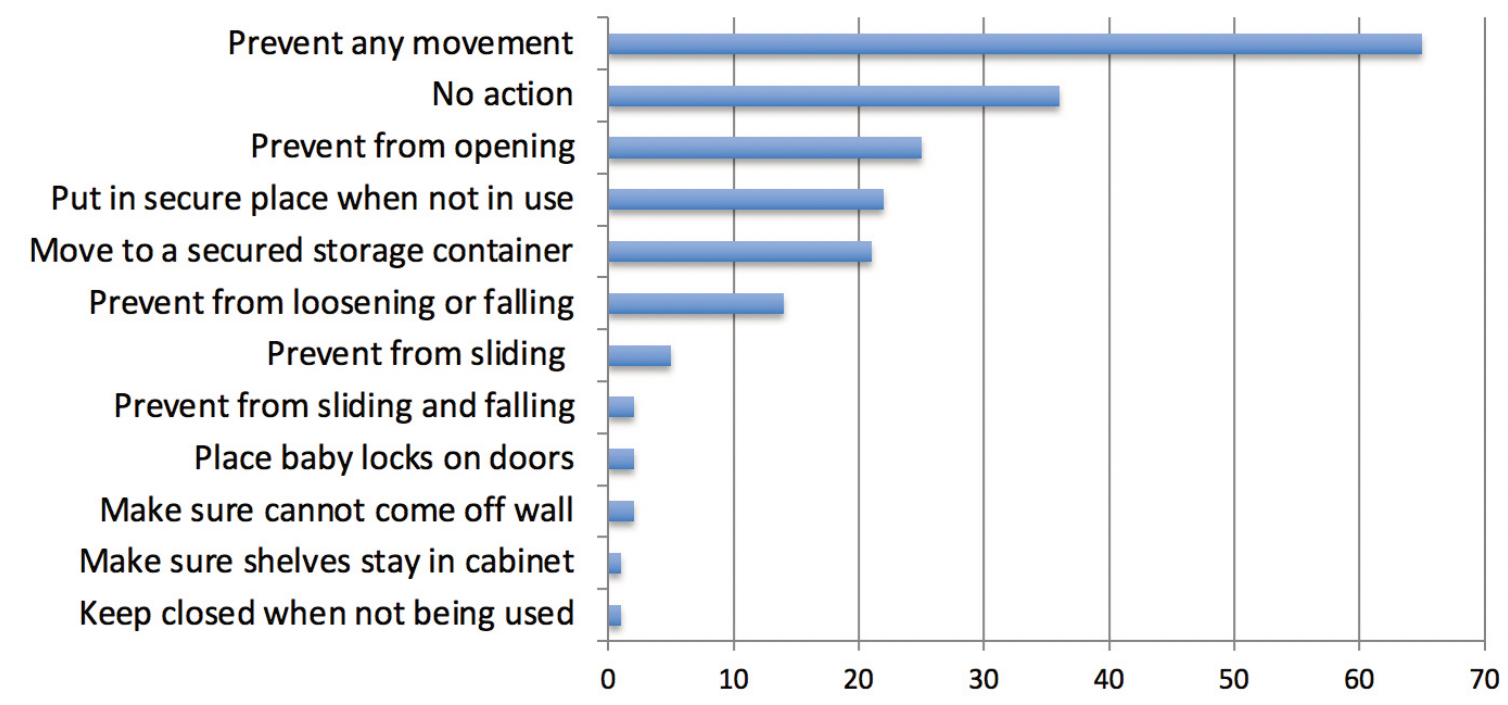

Figure 8. Mitigation categories and frequency of mitigation.

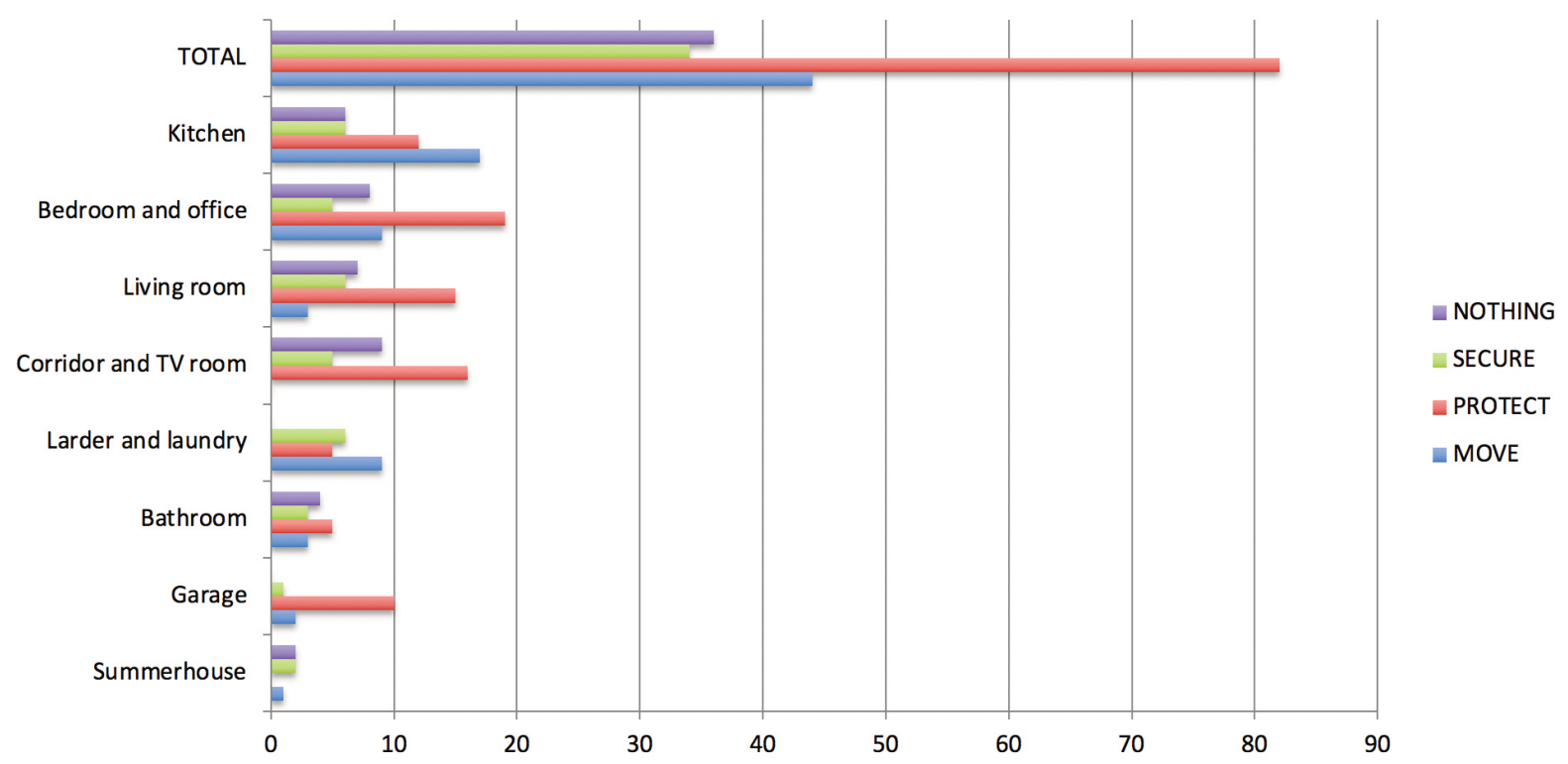

Figure 9. Mitigation type frequency in each room type.

\section{Columns 14-17: Disaster activities required when mitigation is performed}

Preparedness activities are preparations before the earthquake in order to know what to do during the disaster. To know how to prepare, one needs to know what could happen and what activities are needed in response. There are four key earthquake response actions [Thorvaldsdóttir and Sigbjörnsson, 2014]. 


\section{Sólveig Thorvaldsdottir et al.}

- Impact actions: actions taken due to the earthquake shaking, the damaging processes, and any damages needed to be addressed immediately

- Rescue actions: lifesaving actions, including immediate first aid

- Relief actions: temporary actions taken to bridge the gap and relieve suffering until recovery actions are complete

- Recovery actions: actions taken to restore life back to normalcy

Disaster activities (impact, rescue, relief, and recovery) involve reacting to issues listed in the following columns in Figure 4.

- Column 6: reduced functionality

- Columns 7-10: consequences of reduced functionality

- Column 11: secondary impact to other items and people

Disaster response activities needed when no mitigation is performed were determined and listed in Table 4.

\begin{tabular}{|c|c|c|c|}
\hline Impact Activities & Rescue Activities & Relief Activities & Recovery Activities \\
\hline \multirow{2}{*}{$\begin{array}{l}\text { Avoid projectiles } \\
\text { (move to safe or safer } \\
\text { location, duck, cover, } \\
\text { and hold on). }\end{array}$} & $\begin{array}{l}\text { Rescue people that are } \\
\text { trapped under fallen objects. }\end{array}$ & $\begin{array}{l}\text { Emotional relief } \\
\text { Temporary arrangements for the } \\
\text { following: }\end{array}$ & $\begin{array}{l}\text { Clean-up due to chemical } \\
\text { damage }\end{array}$ \\
\hline & $\begin{array}{l}\text { Tend to injuries, send to } \\
\text { hospital if needed, and }\end{array}$ & $\begin{array}{l}\text { Baby eating/seating, Bedding } \\
\text { arrangement, Body washing, }\end{array}$ & $\begin{array}{l}\text { Clean-up due to water } \\
\text { damage }\end{array}$ \\
\hline $\begin{array}{l}\text { Stop water leaks from } \\
\text { heaters, tanks, washing } \\
\text { machine, and } \\
\text { dishwasher. }\end{array}$ & administer first aid. & $\begin{array}{l}\text { Cleaning Clothing, Cloths drying, } \\
\text { Cloths washing, Cold storage, } \\
\text { Communication, Cooking, Curtains, } \\
\text { Doors for privacy, Drinking, Eating, } \\
\text { Food storage, Food supply, Heating, }\end{array}$ & $\begin{array}{l}\text { Clean-up: General } \\
\text { Irreplaceable - emotional } \\
\text { recovery }\end{array}$ \\
\hline $\begin{array}{l}\text { Stop chemical leaks, } \\
\text { e.g., paint. }\end{array}$ & & $\begin{array}{l}\text { Heat water, Ironing, } \\
\text { Lighting, Make coffee, Seating, }\end{array}$ & Purchase normal food \\
\hline Stop chemical leak & & $\begin{array}{l}\text { Storage, Table, Toilet, } \\
\text { Water/drainage (sink) }\end{array}$ & Repair repairable items \\
\hline $\begin{array}{l}\text { from washing } \\
\text { powder/liquids }\end{array}$ & & & Replace irreparable items \\
\hline
\end{tabular}

Table 4. List of disaster response activities

\section{Results}

The results are guidelines for homeowners and residents on how to manage their earthquake risk. Section 5.1 presents an overview, and further explanations of each step are provided in section 5.2. The guidelines encourage discussions among household members on various issues. Therefore, earthquake risk management guidelines are most useful if the entire household participates in developing them.

\subsection{Guidelines: overview of a 14 Step Approach}

The study of damage brought insight into how to operationalize the four pre-earthquake objectives for homes. The results are presented as 12 steps within the four pre-earthquake objectives (Figure 10). 


\section{Understand risk}

STEP 1: Make an inventory

STEP 2: Determine direction of motion

STEP 3: Evaluate the value each item

STEP 4: Consider consequences of damaged items

\section{Mitigate risk to extent possible and sensible}

STEP 5: Decide mitigation options

STEP 6: Estimate the cost of the mitigation options.

STEP 7: Balance options and make a mitigation plan

3. Mitigate risk to extent possible and sensible

STEP 8: Estimate response needed due to residual risk, develop response plan

STEP 9: Draft a preparedness plan to enable the response

STEP 10: Re-evaluate mitigation plan based on preparedness plan

STEP 11: Finalize response and preparedness for response plans

\section{Be ready to learn from experience}

STEP 12: Be ready to record performance of each item

STEP 13: Be ready to evaluate the effectiveness of mitigation measures

STEP 14: Be ready to evaluate the effectiveness of preparedness efforts

Figure 10. Guidelines for non-structural earthquake risk management for residential buildings.

Associated output:

1. Now you should have a good idea of the non-structural items in your home, the physical threat they create, and their value.

2. Now you should have a mitigation plan on how to make your home as safe as possible for the boundaries you have set.

3. Now you should have a preparedness plan on how to respond in the event of a damaging earthquake.

4. Now you should have a plan on how to learn from your experience and be better prepared in the event of aftershocks or further earthquake activity.

\subsection{Explanations of Each Step}

STEP 1: Make an inventory

Make an inventory of non-structural elements in your home. Use Figure 5 to guide you in listing loose items. Use the list below to guide you in making a list of fixed non-structural items.

1. Interior: Partition walls, mortar, ceiling cladding, paintwork/surface treatment.

2. Interior fixtures: Kitchen and bathrooms, doors, flooring, wall tiles, etc.

3. Exterior: Windows, glass, doors, wall cladding, paintwork/surface treatment, etc.

4. Plumbing: Cold water, hot water, sewer pipes, radiators.

5. Electrical installations. 


\section{Sólveig Thorvaldsdottir et al.}

\section{STEP 2: Determine the mode of motion}

Determine the type of motion the item could sustain during an earthquake

- Slide

- Topple

- Fall

Note that some items on the list do not move, e.g., paintwork. However, paintwork can be very costly and should be taken into consideration.

\section{STEP 3: Assess the value of each item}

Items have different values for different people. Some items have emotional value without being expensive. Others are easily replaceable. In order to decide the level of mitigation to use on an item, you have to determine the value the item has to you. Evaluate each item for its financial and emotional value.

- Financial value (Am I willing to suffer financial losses?): For fixed items, seek professional opinion if needed. For loose items, estimate replacement cost for expensive items and those that need to be replaced.

- Emotional value: Judge whether the loss of the item will have an emotional effect on you or members of your household.

Evaluate each item for its value in terms of level of disruption stemming from level of damage in terms of functional value, blockage to passageways, and recovery times. Use Table 5 as the basis of discussion. The answers in Table 5 are subjective. The purpose of the table is not to acquire accurate answers, but to lead those who are filling it in to think about these issues, what they think could happen, and how to eventually address it.

\section{Disruption Categories}

Damage State

Functionality of Item (lack of use)

None

All items are fully functional

Passageway is clear (lack of access)
Functionality of Passageway Recovery Time (time being without item)

Recovery is complete within 1 hour by straightening up or picking things off the floor and

\begin{tabular}{llll}
\hline Minimum/Mild & Minor repairs & $\begin{array}{l}\text { A few items are in } \\
\text { passageway, but easily } \\
\text { avoidable }\end{array}$ & Recovery takes less than 1 day \\
\hline Moderate & $\begin{array}{l}\text { Repairable, but costly } \\
\text { compared to replacement cost }\end{array}$ & $\begin{array}{l}\text { Many items affect } \\
\text { passageway, need to walk } \\
\text { carefully }\end{array}$ & $\begin{array}{l}\text { Recovery takes less than } 1 \\
\text { week }\end{array}$ \\
\hline Extensive & None & $\begin{array}{l}\text { Passageways are completely } \\
\text { blocked }\end{array}$ & $\begin{array}{l}\text { Recovery takes more than } 1 \\
\text { week, especially the } \\
\text { replacement of practical items } \\
\text { and repairs }\end{array}$ \\
\hline
\end{tabular}

Table 5. Damage States and Disruption Categories.

STEP 4: Consider the consequences of damaged items

Most damage bears some sort of consequences. Motion of items can also cause consequences without damage 
to the item. For example, a heavy object may injure a person without itself being damaged. Secondary damage can occur if, for example, paint and chemicals fall on valuables. In order to manage consequence chains, it is helpful to classify consequences. Therefore, evaluate possible consequences from damage or motion based on the following categories:

- Humans (health, injury, death)

- Natural environment

- Economic aspects other than direct replacement costs

- Social activities for household members, including general inconvenience

\section{STEP 5: Decide mitigation options}

Based on the level of threat of physical injury, value and motion, use the KnowRisk Practical Guide to decide what type of mitigation to perform for each item.

- Move

- Protect

- Secure

- Retrofit

- Do nothing: Either because it is difficult, e.g., fixing chairs or tables, or because you are willing to take the consequences, e.g., let a flowerpot fall on the floor.

The damage to fixed non-structural elements is highly dependent on the motion of the building they are attached to and the fixtures that attach them to the building. Mitigation options mainly involve making sure the items are seismically secured. The mitigation options for loose items are more variable. Table 6 lists mitigation options that have been identified in different rooms in a home. The most options per room are in the kitchen. The table is a basis for discussion on possible options to take.

\begin{tabular}{|c|c|}
\hline Room & Mitigation Options for loose items \\
\hline \multirow{9}{*}{ 1. Kitchen } & Keep closed when not being used \\
\hline & Make sure objects cannot come off the walls \\
\hline & Place baby locks on doors \\
\hline & Prevent from loosening or falling during earthquake \\
\hline & Prevent movement during earthquake \\
\hline & Prevent sliding and falling during earthquake \\
\hline & Prevent sliding during earthquake \\
\hline & Put in secure place when not in use: in draws behind baby locked cabinet draws \\
\hline & Shelves usually stay in cabinet, but make sure they do \\
\hline \multirow{3}{*}{ 2.Larder - Laundry } & Move loose items to a secured storage container \\
\hline & Prevent loosening and falling during earthquake \\
\hline & Prevent movement during earthquake \\
\hline \multirow{4}{*}{ 3. Corridor - TV room } & Prevent from loosening or falling during earthquake \\
\hline & Prevent movement during earthquake \\
\hline & Prevent opening during earthquake \\
\hline & Prevent sliding during earthquake \\
\hline \multirow{6}{*}{ 4. Bedroom and office } & Make sure cannot come off wall \\
\hline & Move loose items to a secured storage container \\
\hline & Place baby locks on doors \\
\hline & Prevent from loosening or falling during earthquake \\
\hline & Prevent movement during earthquake \\
\hline & Prevent sliding during earthquake \\
\hline
\end{tabular}




\section{Sólveig Thorvaldsdottir et al.}

\begin{tabular}{ll}
\hline 5. Garage & Move loose items to a secured storage container \\
\hline \multirow{2}{*}{ 6. Bathroom } & Prevent movement during earthquake \\
\hline & $\begin{array}{l}\text { Prevent movement during earthquake } \\
\text { Prevent opening during earthquake }\end{array}$ \\
\hline Prevent from loosening or falling during earthquake \\
\hline Put in secure place when not in use: in draws behind baby locked cabinet draws \\
\hline Prevent movement during earthquake \\
\hline Prevent opening during earthquake \\
\hline
\end{tabular}

Table 6. Mitigation options identified in different rooms in a home.

\section{STEP 6: Estimate the cost of the mitigation options}

After deciding which mitigation options to take, estimate how much those will cost. It is a good idea to also estimate the cost of effort, for instance, putting things away after use. If household members are not likely to follow such a rule, discuss whether a better option should be chosen.

\section{STEP 7: Balance options and make a mitigation plan}

After the list is complete, balance the cost against the values of the items and the physical threat to make a realistic list of the mitigation measures that you plan to implement. If the cost it too high, adjust your plan according to your budget.

\section{STEP 8: Estimate response needed due to residual risk and develop response plan}

It is unlikely that all risk will be mitigated. There is still a risk of damage, loss of function and injury, i.e., the residual risk. Determine what response activities would be required to deal with damage and consequences from the residual risk. Next, determine what type of preparedness activities are needed. For example, if you find that damage could lead to fire and your plan is to put the fire out, you need to prepare by buying a fire extinguisher. Use Table 7 as a basis for discussion on determining response activities, i.e., impact, rescue, relief, after relief and recovery activities.

STEP 9: Draft a preparedness plan to enable the response

After your discussions in step 8, draft a plan on what you need to do in order to be prepared to respond in the event of an earthquake. Before finalizing it, move onto step 10.

\section{STEP 10: Re-evaluate mitigation plan based on preparedness plan}

Revaluate your mitigation plan based on efforts required for the preparedness and the response activity. In your re-evaluation, estimate the number of items that would need to be replaced or would lose their function and use that to judge the overall functionality of your home. Is each room still useable? Could you still live in the home? Would you need to relocate? To where? For how long? When making your final mitigation and preparedness plans, imagine yourself in these post-earthquake circumstances and then implement your plan!

\section{STEP 11: Finalize response and preparedness for response plans}

Once you have re-evaluated your mitigation plan, finalize your preparedness for response plan. Make copies for every member in the household. 


\begin{tabular}{|c|c|}
\hline $\begin{array}{l}\text { Preparedness } \\
\text { type }\end{array}$ & Preparedness activity \\
\hline $\begin{array}{l}\text { Impact } \\
\text { Preparedness }\end{array}$ & $\begin{array}{l}\text { - Ponder what building content could become projectiles and where to go in an earthquake to } \\
\text { avoid being hit my them (for each room) } \\
\text { - How to stop water and chemical leaks. What tools are needed? } \\
\text { - Is it likely that there will be a need from official fire services to stop leaks? Do you know how to } \\
\text { call for their help? }\end{array}$ \\
\hline $\begin{array}{l}\text { Rescue } \\
\text { Preparedness }\end{array}$ & $\begin{array}{l}\text { - One's ability to rescue people from under heavy fallen objects. What items are needed? } \\
\text { - One's ability to address injuries. Prepare a first aid kit and take a course. } \\
\text { - Is it likely that there will be a need from official rescue services? Do you know how to call for } \\
\text { their help? }\end{array}$ \\
\hline $\begin{array}{l}\text { Relief } \\
\text { Preparedness }\end{array}$ & $\begin{array}{l}\text { - Does one have the ability to provide own temporary arrangements? Is it necessary to buy simple } \\
\text { items for temporary use, e.g., plastic cutlery, dishes, containers, chairs, tables, washing clothes } \\
\text { by hand, and other items that are unlikely to be damaged during an earthquake to use for } \\
\text { temporary arrangements? Could these items be the camping gear? } \\
\text { - Be prepared to quickly judge whether the family can stay in the house or whether the state of } \\
\text { the house is such that you need to move out. Think of paces where to move the item. Know } \\
\text { where your mass care shelter is located. } \\
\text { - Consider possibilities if temporary relocation is required during repair and replacement work } \\
\text { during recovery. } \\
\text { - Know how to call for assistance from relief services. }\end{array}$ \\
\hline $\begin{array}{l}\text { Recovery } \\
\text { Preparedness }\end{array}$ & $\begin{array}{l}\text { - One's ability to provide own recovery arrangements. What is needed for cleaning up? Cleaning } \\
\text { equipment, shoes, etc. } \\
\text { - One's likely needs from official recovery services. } \\
\text { - Know whom to contact for recovery assistance. } \\
\text { - Consider the time it may take to recover from the event. } \\
\text { - Consider financial cost of recovery. }\end{array}$ \\
\hline
\end{tabular}

Table 7. Preparedness options for residents based on preparedness type.

STEP 12: Be ready to record the performance of each item

Add columns to your inventory list to record information about motion, repair cost, and loss of functionality to be ready to record information in the event of an earthquake. Make reminders for yourself to take pictures before cleaning up so you do not need to delay the clean-up due to recording events. Photographs are useful for insurance purposes and to assist in academic research.

STEP 13: Be ready to evaluate the effectiveness of mitigation measures

- Keep a copy of your mitigation plan

- Maintain a record of what was completed from the plan and how much it cost

- Review the success of your mitigation efforts in terms of actual damage and consequence during an earthquake

- Determine whether you need to take immediate mitigation measures due to potential aftershocks

- Re-evaluate your long-term mitigation plan to be ready for future earthquakes

\section{STEP 14: Be ready to evaluate the effectiveness of preparedness efforts}

- Keep a copy of your preparedness plan

- Maintain a record of what was completed from the plan and how much it cost

- Based on what happened, make a judgement of your pre-earthquake activities

- Re-evaluate your preparedness actions to be ready for aftershocks and future earthquakes 


\section{Sólveig Thorvaldsdottir et al.}

\section{Discussion}

While the guidelines were developed based on damage data from the most affected areas of the $\mathrm{M}_{\mathrm{W}} 6.5$ and 6.5 earthquakes in south Iceland, the resulting procedures are not associated with the ground shaking intensity or level of damage. The observed damage was used to indicate what could be expected in terms of damage and consequences in general. Therefore, the guidelines are applicable to any location in the South Iceland Seismic Zone, close to or far away from the 2000 and 2008 epicentres. They are not limited to the study area and can be applied to any seismically active region in the world. Furthermore, they are relevant to any building use, such as, offices, hospitals, and services. They could potentially be adapted to any hazard type.

As societies become more complex, non-structural elements become critical parts of sound earthquake risk management. However, it is unrealistic to expect people to live in $100 \%$ earthquake risk mitigated homes. That would require table and chairs nailed to the floor and people putting all items away into secured containers immediately after use. The study shows that do nothing will sometimes be inevitable. In the context of determining mitigation measures, the guidelines presented herein ask residents to balance their options between mitigation and preparedness, the more the mitigation the less the preparedness. The message to the residents is to make informed and balanced decisions. Are they willing to skip mitigation and deal with the consequences? By giving people a good understanding of what could happen, they have a say in the expected consequences in their home and might be more likely to be more accepting of the real consequences. Residents are asked to consider the overall functionality of the home and are asked to judge whether they may need to move out of their home due to damage to non-structural items. Reflecting on what the loss of function means to residents helps them to make decisions on when to mitigate and when to simply prepare to deal with the consequences.

The Earthquake Engineering Research Institute provides guidelines on how to develop earthquake scenarios [EERI, 2006] and various completed scenarios (https:/www.eeri.org/projects/earthquake-scenarios/). The results presented here provide additional detail to such pre-existing guidelines.

\section{Conclusion}

From the study, we conclude that, while fixed and loose non-structural components are grouped together as non-structural components, they are very different from an earthquake risk management perspective. While attention in the literature to fixed components is justified, more attention is needed on building contents. The more our day-to-day lives are dependent on the contents we place inside buildings, the more vulnerable we are to their loss of function and the more we need to apply disaster risk management. A logical step is to use clearer terminology, for example, "building contents" for "loose non-structural components".

Photos are critical to understanding the context of items and help to bring attention to things that are normally taken for granted until they are no longer functional, such as, doors and curtains that provide privacy. Disaster research has shown that problems with the lack of privacy are of key concern in large open area shelters; privacy is also important in homes. More work is needed on understanding the damage to building contents in context with their surroundings and the vulnerability of different types of facilities.

The present work proposes a systematic way of preparing guidelines for household seismic resiliency regarding building contents. It relies on sound principles of disaster risk management to help residents understand potential risks, apply mitigation measures where feasible, and prepare for residual risk. The resulting guidelines are not a complete to-do list, but a step-by-procedure to help residents make informed decisions on mitigating and managing impending risk. The procedures and steps outlined here, being based on general disaster risk management principles, are adaptable to different socioeconomic and cultural situations and potentially to other natural hazards.

Acknowledgements. This paper was co-financed by the EC, DIRECTORATE-GENERAL HUMANITARIAN AID AND CIVIL PROTECTION - ECHO, AGREEMENT NUMBER - ECHO/SUB/2015/718655/PREV28, Prevention and preparedness projects in civil protection and marine pollution. Prevention Priorities through the Project 'KnowRISK, Know your city, Reduce selSmic risK through non-structural elements'. We acknowledge constructive comments from two anonymous reviewers. 


\section{References}

ATC 13 (1985). Earthquake damage evaluation data for California, ATC 13, Applied Technology Council (ATC), Redwood city, CA.

Bessason, B., J.Ö. Bjarnason, (2016). Seismic vulnerability of low-rise residential buildings based on damage data from three earthquakes (M w 6.5, 6.5 and 6.3), Eng. Struct., 111, 64-79.

Bessason, B., J.Ö. Bjarnason, A. Guðmundsson, J. Sólnes, S. Steedman (2014). Analysis of damage data of low-rise buildings subjected to a shallow Mw6.3 earthquake, Soil Dyn. Earthq. Eng., 66, 89-101.

Bessason, B., J.Ö. Bjarnason, R. Rupakhety (2020). Statistical modelling of seismic vulnerability of RC, timber and masonry buildings from complete empirical loss data. Eng. Struct., 209, 109969.

CEN (2005). EN 1991-1-4:2005 - Actions on structures - Part 1-4: General actions - Wind actions, European Committee for Standardization (CEN).

Colombi, M., B. Borzi, H. Crowley, M. Onida, F. Meroni, R. Pinho (2008). Deriving vulnerability curves using Italian earthquake damage data, Bull. Earthq. Eng., 6, 485-504.

DFID, Department for International Development (1999). Sustainable Livelihoods Framework Guidelines, http://www.ennonline.net/resources/667, extracted June 2, 2013.

Dolce, M., A. Kappos, A. Masi, G. Penelis, M. Vona (2006). Vulnerability assessment and earthquake damage scenarios of the building stock of Potenza (Southern Italy) using Italian and Greek methodologies, Engineering Structures, 28, 351-357.

EERI (2006). Guidelines for Developing an Earthquake Scenario, http://mitigation.eeri.org/files/Developing.a.Scenario.pdf.

Einarsson, P. (1991). Earthquakes and present-day tectonism in Iceland, Tectonophysics, 189,1, 261-279.

FEMA E-74 (2011). Reducing the risks of nonstructural earthquake damage - A practical guide, Federal Emergency Management Agency, Washington, DC

FEMA 232 (2006). Homebuilders' Guide to Earthquake-resistant Design and Construction, Building Safety Council, National Institute of Building Sciences, Washington, D.C.

Ferreira, M.A., F. Meroni, R. Azzaro, G. Musacchio, R. Rupakhety, B. Bessason, S. Thorvaldsdottir, M. Lopes, C.S. Oliveira, S. Solarino (2021). What scientific information on the seismic risk to non-structural elements do people need to know? Part 1: Compiling an inventory on damage to non-structural elements, Ann. Geophys., 64, this issue.

Halldórsson, B., R. Sigbjörnsson (2009). The Mw6.3 Ölfus earthquake at 15:45 UTC on 29 May 2008 in South Iceland: ICEARRAY strong-motion recordings, Soil Dyn. Earthq. Eng., 29, 1073-83.

Halldórsson, P., S. Björnsson, B. Brandsdóttir, J. Sólnes, R. Stefánsson, B. Bessason (2013). Earthquakes in Iceland, In: Sólnes J, Sigmundsson F, Bessason B (eds.), Natural Hazard in Iceland, Volcanic Eruptions and Earthquakes, University of Iceland Press and Iceland Catastrophe Insurance (in Icelandic).

Ioannou, I, B. Bessason, I. Kosmidis, J.Ö. Bjarnason, T. Rossetto (2018). Empirical Seismic Vulnerability Assessment of Icelandic Buildings Affected by the 2000 Sequence of Earthquakes, Bull. Earthq. Eng., 16, 12, 5875-5903,

ÍST 13 (1976). Earthquakes, loads and design rules, Reykjavík, Iðnnróunarstofun Íslands.

Jóhannesson, H., S.P. Jakobsson, K. Sæmundsson (1982). Geological map of Iceland, sheet 6, S-Iceland, Icelandic Museum of Natural history and Iceland Geodetic Survey, Reykjavik, Iceland.

Miranda, E., G. Mosqueda, R. Retamales, G. Pekcan (2012). Performance of Nonstructural Components during the February 27, 2010 Chile Earthquake, Earthquake Spectra, 28, S1, S453-S471.

Natural Catastrophe Insurance of Iceland (2020). http://www.nti.is/en/. Accessed 10 August 2020.

NIST (2018). Recommendations for Improved Seismic Performance of Nonstructural Components, Report NIST GCR 18-917-43 prepared by the Applied Technology Council for the U.S. Department of Commerce Engineering Laboratory National Institute of Standards and Technology, Gaithersburg, MD, USA.

Ólafsson, S. (2013). Attenuation of earthquake waves. In: Sólnes J, Sigmundsson F, Bessason B (editors). Natural Hazard in Iceland, Volcanic Eruptions and Earthquakes: University of Iceland Press and Iceland Catastrophe Insurance, (in Icelandic).

Ólafsson, S. (1999). Estimation of earthquake-induced response, (Ph.D. thesis 1999:75), Institute for Marine Structures, NTNU, Norway.

Ólafsson, S., R. Sigbjörnsson R (2002). Attenuation of strong-motion in the South Iceland Earthquakes of June 2000, Proceedings of the 12th European conference on earthquake engineering, CD-disk, London, Elsevier, Paper 


\section{Sólveig Thorvaldsdottir et al.}

412.

Park, Y.J., AH-S. Ang (1984). Mechanistic seismic damage model for reinforced concrete, J. Struct. Eng, ASCE, 111, ST4, 722-739.

Pujols, J.C.G., K.L. Ryan (2016). Development of Generalized Fragility Functions for Seismically Induced Content Disruption, Earthquake Spectra, 32, 3, 1303-1324

Perrone, D., P.M. Calvi, R. Nascimbene, E. Fischer, G. Magliulo (2019). Seismic Performance and Damage Observation of Non-Structural Elements During the 2016 Central Italy Earthquake, Bull. Earthq. Eng, 17, 5655-5677.

Registers Iceland (2020). https://www.skra.is/english/individuals, Accessed 10 August, 2020.

Rossetto T, Elnashai A (2003). Derivation of vulnerability functions for European-type RC structures based on observational data, Eng. Struct., 25, 1241-1263.

Rupakhety, R., R. Sigbjörnsson, S. Ólafsson (2016) S. Damage to residential buildings in Hveragerði during the 2008 Ölfus Earthquake: simulated and surveyed results. Bull. Earthq. Eng., 1, 14,7, 1945-55.

Sigbjörnsson, R., J.T. Snæbjörnsson, S. M. Higgins, B. Halldórsson, S. Ólafsson (2009). A note on the Mw6.3 earthquake in Iceland on 29 May 2008 at 15:45 UTC, Bull. Earthq. Eng.., 7,1, 113-126.

SI (2002). National Application Documents (NAD) for Iceland, Standards Council of Iceland/ Staðlaráð Íslands.

SI (2010). Icelandic National Annexes to Eurocodes, Standards Council of Iceland/ Staðlaráð Íslands.

Sólnes, J., R. Sigbjörnsson, and J. Elíasson (2004). Probabilistic seismic hazard mapping of Iceland, Proceedings of the 13th World conference on earthquake engineering, Vancouver, BC, Canada.

Taghavi, S., E. Miranda (2003), Response assessment of non-structural building elements, PEER 2003/05, Pacific Earthquake Engineering Research Center.

Thorvaldsdóttir, S. (2006). Vulnerability Study of the South-Iceland Lowland Based on Data from the 2000 Earthquakes, FORESIGHT Project GOCE-CT-2003-511139, $6^{\text {th }}$ European Framework Programme.

Thorvaldsdóttir, S., R. Sigbjörnsson R. (2014) Disaster Function Management: Basic Principles, Nat. Hazards Rev., $15,19,48-57$.

Thórarinsson Ó., B. Bessason, J. Snæbjörnsson, S. Ólafsson, R. Sigbjörnsson, G. Baldvinsson (2002). The South Iceland earthquakes 2000: Strong motion measurements, Proceedings of the 12th European Conference on Earthquake Engineering, Paris, France.

Tryggvason E., S. Thoroddsen, S. Thorarinsson (1958). Report on earthquake risk in Iceland, Tímarit Verkfræðingafélags Îslands, 43, 81-97. 